\title{
Corn yield in sandy soil fertilized with poultry litter
}

\author{
Juliana da Silva Barros', João Carlos Medeiros ${ }^{2 *}$, Jaqueline Dalla Rosa ${ }^{3 *}$, Julian Junio de Jesus Lacerda², \\ Daiane Conceição de Sousa ${ }^{4}$, Maria Sueli Heberle Mafra ${ }^{5}$
}

${ }^{1}$ Master Student, Universidade Estadual Paulista, Botucatu, SP, Brazil, ${ }^{2}$ Professor in Soil Science, Universidade Federal do Piauí, Bom Jesus, PI, Brazil, ${ }^{3}$ Post Doctor of the PPG in Soil and Plant Nutrition, Universidade Federal do Piauí, Bom Jesus, PI, Brazil, ${ }^{4}$ Master in Soil Science. Universidade Federal do Piauí, Bom Jesus, PI, Brazil, ${ }^{5}$ Post Doctor of the Post Graduate Program in Health and Environment, Universidade do Planalto Catarinense, Lages, SC, Brazil

\section{A B S TR A C T}

\begin{abstract}
The use of animal waste is an alternative to provide nutrients and increase organic matter content in sandy soils. The poultry litter is one of the most nutrient-rich residues. The objective of this study was assess the effect of poultry litter as organic fertilizer on productivity of corn and chemical properties of a sandy soil. The experiment was conducted at the experimental farm of the Federal University of Piauí, in the municipality of Bom Jesus, PI, Brazil. The treatments were poultry litter levels: 0 (control), 2, 4, 8, 12, 16 and $24 \mathrm{t} \mathrm{ha}^{-1}$. We evaluated the effect of poultry litter on the soil chemical properties, plant growth and productivity of corn. We also evaluated the correlation between variables of the plant and soil chemical properties. The maximum productivity was obtained with the highest level poultry litter $\left(24 \mathrm{t} \mathrm{ha}^{-1}\right)$. Calcium, magnesium, phosphorus, potassium, $\mathrm{pH}$, and soil organic matter increased due to the increase of poultry litter levels. The soil chemical properties have positive relationship with stem diameter and productivity of corn. The poultry litter is an organic fertilizer with potential of increase the productivity of the corn and meliorate the fertility of sandy soils.
\end{abstract}

Keywords: Organic fertilizer; Animal waste; Soil fertility

\section{INTRODUCTION}

The use of organic waste derived from animal production is a common practice in agricultural crops, replacing chemical fertilizers (totally or partially). This practice aims the increase in crop yield and may reduce production costs, especially in small farms where these wastes are usually available (Santos et al., 2010).

Brazil is the third largest world producer of broiler chicken in the world and generates 6.8 million $\mathrm{m}^{3}$ year $^{-1}$ of poultry litter (Embrapa Suínos and Aves, 2015). Among the animal wastes, the poultry litter is the one with the highest nutrient concentration (Silva, 2008). This occurs because the rations present high nutrient concentration and low digestibility in the bird's digestory tract, resulting in high concentration of nutrients in the wastes (Konzen and Alvarenga, 2005). Thus, the use of poultry litter as an organic fertilizer is justified by the composition rich in nutrients, reducing the need of mineral fertilizers.
Studies have shown beneficial effect of using poultry litter as fertilizer in the production of annual crops. The use of increasing levels of poultry litter provides a significant increase in corn production (Bayer et al., 1999; Konzen, 2003; Novakowiski et al., 2013). Similarly, the bean yield with poultry litter fertilization was similar to mineral fertilization (Andreola et al., 2000). Other benefits of its use are the improvement of soil quality, the reduction of soil and water pollution, impacting in the farming systems sustainability (Figueiredo et al., 2012).

Besides providing nutrients to plants, the organic fertilizers improve the soil structure by adding organic matter, especially in sandy soils. The increase of organic matter in sandy soils is especially important because it increases the water retention and the cation exchange capacity (Brady, 2013), favoring the development of crops. After a long period of poultry litter and pig slurry application in different systems for using the soil, Rauber et al. (2005) verified improvement in soil structure by increasing the aggregates stability, and bulk density and soil resistance

\footnotetext{
${ }^{*}$ Corresponding author:

Jaqueline Dalla Rosa, Post doctor of the PPG in Soil and Plant Nutrition, Universidade Federal do Piauí, Bom Jesus, PI, Brazil.

E-mail: jaqueline.dr@gmail.com
}

Received: 03 March 2017;

Revised: 29 November 2017;

Accepted: 05 December 2017;

Published Online: 25 December 2017 
to penetration below critical values. The organic fertilizer (bovine manure) improves the initial development of sugarcane plant in sandy soils of Brazilian Savannah and may be a way to facilitate the sugarcane cultivation in this soil type (Fonseca et al., 2016).

Therefore, the poultry litter can bring benefits to the productive agricultural system, by supplying nutrients, complementing mineral fertilization and improving chemical properties in sandy soils. However, in sandy soils of Brazilian Savannah, there is little information on its use as fertilizer and its efficiency in corn fertilization. Thus, this study was conducted with the aim of evaluate poultry litter levels complementing mineral fertilization on corn yield and chemical attributes of a sandy soil.

\section{MATERIALS AND METHODS}

\section{Study location}

The experiment was performed at the experimental farm of the Federal University of Piauí, in Bom Jesus, PI, Brazil. The geographic location coordinates are: $09^{\circ} 04^{\prime} 28^{\prime \prime} \mathrm{S}$ and $44^{\circ} 21^{\prime} 55.2 \mathrm{~W}$, and $270 \mathrm{~m}$ of altitude. The regional climate is tropical (AW) with dry season in the winter and rainy in the summer. The average annual rainfall is $950 \mathrm{~mm}$, concentrated from October to April. The average temperature is $26.5^{\circ} \mathrm{C}$ while the air relative humidity is 68\% (Andrade Junior et al., 2004).

The soil, of the experimental area, is a Quartzarenic Neosol (Embrapa, 2013).The chemical composition of the soil, in the $0-0.20 \mathrm{~m}$ deep layer, before the experiment instalation is described in Table 1.

\section{Experimental design and treatments application}

The experimental was performed in a randomized block design with seven treatments and three replications. The experimental units were plots of $5 \times 6.5 \mathrm{~m}$ totaling $32.5 \mathrm{~m}^{2}$. The treatments were composed of poultry litter levels: $0,2,4,8,12,16$ and $24 \mathrm{tha}^{-1}$. The application was performed manually in August 2014. After the doses distribution on the soil, they were incorporated with two disking, until $0.20 \mathrm{~m}$ deep. The poultry litter was analyzed for nutritional composition (Table 2). The amount of nutrients available for the plants was calculated for each level by the equation (1), based on the dry matter and the conversion rate of the organic forms to the inorganic forms (Furtini Neto 2001; Malta et al. 2007) and modified by Silva (2008)

$\mathrm{NOF}=[\mathrm{A} /(\mathrm{B} / 100 \mathrm{xC} / 100 \mathrm{xD} / 100)] \mathrm{xE}$

Where:

NOF: Need for organic fertilization (amount of solid organic fertilizer to be applied, $\left.\mathrm{kg} \mathrm{ha}^{-1}\right)$;

A: Nutrient amount required by the crop $\left(\mathrm{kg} \mathrm{ha}^{-1}\right)$;

B: Dry matter content in the residue (\%);

C: Nutrient content in dry matter $(\%)$;

D: Conversion rate $(\%)$;

E: Correction factor for the type of crop (annual or perennial).

The corn sowing was performed at the beginning of March 2015. During the sowing, $46 \mathrm{~kg}$ of $\mathrm{P}_{2} \mathrm{O}_{5} \mathrm{ha}^{-1}$ were applied as triple superphosphate (TSP) in the planting line. The line spacing was $0.9 \mathrm{~m}$, and there was a population of 10 plants per linear meter. The final population was of 75,000 plants per hectare.

Thirty days after the emergency, the nitrogen fertilization was applied with $50 \mathrm{~kg}$ of $\mathrm{N} \mathrm{ha}^{-1}$, as urea. During corn development, chemical control of pests and invasive herbs was carried out to avoid interference in the applied treatments.

\section{Evaluation of soil chemical attributes}

After the corn harvest, soil samples were collected in the 0-0.20 $\mathrm{m}$ deep layer for soil chemical analysis. Five simple samples were collected from each plot, four in the interrow and one in the row. They were homogenized to make a composed sample per plot.

The chemical attributes evaluated in the soil were: $\mathrm{pH}$ in $\mathrm{CaCl}_{2}(0.01 \mathrm{M})$, organic matter $(\mathrm{OM})$, phosphorus $(\mathrm{P})$, potassium $\left(\mathrm{K}^{+}\right)$calcium $\left(\mathrm{Ca}^{2+}\right)$ and magnesium $\left(\mathrm{Mg}^{2+}\right)$, analyzed according to methodology described by Silva (2009). P and $\mathrm{K}^{+}$were extracted with Mehlich extractor solution and determined by colorimetry and flame photometry, respectively. $\mathrm{Ca}^{+2}$ and $\mathrm{Mg}^{+2}$ were extracted in $1 \mathrm{M} \mathrm{KCl}$ and determined by atomic absorption spectrophotometry. The $\mathrm{pH}$ in $\mathrm{CaCl}_{2}$ was determined at the ratio of 1:2.5 (soil: $\mathrm{CaCl}_{2}$ solution $(0.01 \mathrm{M})$ ). The wet oxidation method with potassium dichromate and titration with ferrous sulfate was used to determine organic matter (Walkley and Black, 1934).

Table 1: Soil chemical attributes in 0-0.20 m depth layer of the experimental area before the experiment implantation

\begin{tabular}{|c|c|c|c|c|c|c|c|c|c|c|c|c|c|c|}
\hline \multirow{2}{*}{$\mathrm{pH}$} & \multirow{2}{*}{ OM g kg ${ }^{-1}$} & \multirow[t]{2}{*}{$P \mathrm{mg} \mathrm{dm}^{-3}$} & \multicolumn{7}{|c|}{ cmolc dm $\mathrm{dm}^{-3}$} & \multicolumn{5}{|c|}{$\%$} \\
\hline & & & $K$ & $\mathrm{Ca}$ & $\mathrm{Mg}$ & Al & $\mathrm{H}+\mathrm{Al}$ & SB & CEC & V & $\mathrm{m}$ & $\mathrm{Ca}$ & Mg & K \\
\hline 5.5 & 7.4 & 146 & 0.12 & 1.45 & 0.26 & 0.0 & 0.51 & 1.83 & 2.34 & 78 & 0 & 62 & 11 & 5 \\
\hline
\end{tabular}

pH: hydrogen potential, performed in $\mathrm{CaCl} 2$ saline solution, OM: Organic matter, P: phosphorus, K: potassium, Ca: calcium, Mg: magnesium, Al: aluminum, $\mathrm{H}+\mathrm{Al}$ : hydrogen+aluminum, SB: sum of bases, CEC: cation exchange capacity, V: saturation for bases, m: Saturation of CEC by aluminum 


\section{Evaluation in plants and corn yield}

Plant evaluations were performed when the crop reached the V8 stage. In each plot, the 4 central rows were used and 10 plants were randomly selected. In these plants, plant height $(\mathrm{PH})$ was obtained with the aid of a scale, measuring from the soil level to the apical part of each plant; and stem diameter (SD) was obtained with a digital caliper. The plants and grains were harvested 110 days after sowing. To evaluate corn yield, the ears of previously selected plants were harvested and threshing to obtain the grain mass. Then, the yield was calculated in $\mathrm{kg} \mathrm{ha}^{-1}$ with grain moisture correction to $13 \%$ of moisture.

\section{Statistical analysis}

Initially, data of corn production components and soil chemical analysis were submitted to analysis of variance by the $\mathrm{F}$ test, at $5 \%$ of probability. Subsequently, for the significant variables, the regression analysis was performed for the poultry litter levels factor, through SAS statistical program.

\section{RESULTS AND DISCUSSION}

The results of the analysis of variance (Table 3 ) indicate a significant effect of the use of poultry litter levels for the analyzed variables, except for plant height $(\mathrm{pH})$.

Effect of poultry litter levels on soil chemical attributes The soil $\mathrm{pH}$ increased linearly with the increase of poultry litter levels (Fig. 1A). Similar results were found by Blum et al. (2003) who verified a linear increase in $\mathrm{pH}$ and

Table 2: Concentration of nutrients in poultry litter and amount available to the plants in each levels utilized

\begin{tabular}{lcccccc}
\hline Level $\left(\mathbf{t ~ h a}^{-1}\right)$ & \multicolumn{5}{c}{$\mathbf{g ~ k g}^{-1}$} \\
\cline { 2 - 7 } & $\mathbf{N}$ & $\mathbf{P}_{2} \mathrm{O}_{5}$ & \multicolumn{5}{c}{$\mathrm{K}_{2} \mathbf{O}$} & $\mathbf{C a}^{2+}$ & $\mathbf{M g}^{2+}$ & $\mathbf{S}$ \\
\cline { 2 - 7 } & $\mathbf{5}$ & $\mathbf{5 8}$ & $\mathbf{3 4}$ & $\mathbf{2 6}$ & $\mathbf{6 . 1}$ & $\mathbf{5 . 2}$ \\
\hline 2 & 8.55 & 31.32 & 30.6 & 11.7 & 2.745 & 2.34 \\
4 & 17.1 & 62.64 & 61.2 & 23.4 & 5.49 & 4.68 \\
8 & 34.2 & 125.28 & 122.4 & 46.8 & 10.98 & 9.36 \\
12 & 51.3 & 187.92 & 183.6 & 70.2 & 16.47 & 14.04 \\
16 & 68.4 & 250.56 & 244.8 & 93.6 & 21.96 & 18.72 \\
24 & 102.6 & 375.84 & 367.2 & 140.4 & 32.94 & 28.08 \\
\hline
\end{tabular}

$\mathrm{N}$ : nitrogen, $\mathrm{P}_{2} \mathrm{O}_{5}$ : phosphorus, $\mathrm{K}_{2} \mathrm{O}$ : potassium, Ca: calcium,

$\mathrm{Mg}$ : magnesium, S: sulfur reduction of exchangeable aluminum. They also emphasize that with very high levels of poultry litter, the $\mathrm{pH}$ may interfere in the availability of nutrients in the soil. Likewise, $\mathrm{pH}$ elevation was verified in a Oxisol, after 4 years of poultry litter addition (Scherer and Nesi, 2009).

The organic matter at the end of corn cultivation was positively altered by the addition of poultry litter levels, presenting increasing linear effect (Fig. 1B). The organic matter content increased from $8.7 \mathrm{~g} \mathrm{dm}^{-3}$ in the control to $34.7 \mathrm{~g} \mathrm{dm}^{-3}$ when a larger level of poultry litter was used. The increase of the organic matter content becomes important for the sandy soils because it improves the soil structure, increases water retention and CEC (Brady, 2013). Due to the higher amount of sand in the soil, these soils have poor soil structure, low CEC and low water retention, so the increase in OM plays an important role favoring the nutrients availability.

Increasing levels of poultry litter resulted in calcium increased (Fig. 2A), with quadratic effect for the doses used. The calcium content was 11.7 and $140.4 \mathrm{~kg} \mathrm{ha}^{-1}$ with poultry litter at doses of 2 and $24 \mathrm{tha}^{-1}$, respectively (Table 2). This shows that the amount of $\mathrm{Ca}^{2+}$ provided by poultry litter was higher than the quantity that is demanded by the plants, resulting in calcium increase in the soil. The use of poultry litter, applied during four years under no-tillage system, increased this element content in the soil up to the $0.20 \mathrm{~m}$ layer (Scherer and Nesi, 2009). The increase in $\mathrm{Ca}^{2+}$ by the use of poultry litter levels was also verified by other authors (Gomes et al., 2005; Carvalho et al., 2011). Increasing levels of poultry litter also resulted in a significant increasing linear effect for $\mathrm{Mg}^{2+}$ contents (Fig. 2B).

$\mathrm{K}$ and $\mathrm{P}$ levels presented a quadratic response in relation to the application of increasing levels of poultry litter (Fig. 2C and D). Using a dose of $2 \mathrm{tha}^{-1}$ of poultry litter, 30.6 and $31.32 \mathrm{~kg} \mathrm{ha}^{-1}$ of $\mathrm{K}_{2} \mathrm{O}$ and $\mathrm{P}_{2} \mathrm{O}_{5}$ were added, respectively. For the highest level used $\left(24 \mathrm{t} \mathrm{ha}^{-1}\right), 367.2$ and $375.84 \mathrm{~kg} \mathrm{ha}^{-1}$ of $\mathrm{K}_{2} \mathrm{O}$ and $\mathrm{P}_{2} \mathrm{O}_{5}$ were added respectively (Table 2).

These results are similar to those observed by Andreola et al. (2000) and by Moreti et al. (2007) who observed an increase in $\mathrm{K}$ content in the soil when poultry litter was added. Likewise, increasing levels of extractable P were verified by increasing

Table 3: Analysis of variance of the data after poultry litter levels on sandy soil

\begin{tabular}{lccccccccc}
\hline SV & SD & pH & PROD & Ca & Mg & K & P & OM & pH \\
\hline Treatment & $7,189^{*}$ & $0,026^{\text {ns }}$ & $1581^{* *}$ & $4,006^{* *}$ & $0,071^{*}$ & $0,024^{* *}$ & $3529^{* *}$ & $263,44^{* *}$ & $0,249^{*}$ \\
Block & $5,297^{\text {ns }}$ & $0,036^{\text {ns }}$ & $2226^{* *}$ & $0,018^{\text {ns }}$ & $0,070^{\text {ns }}$ & $0,001^{\text {ns }}$ & $8,1^{\text {ns }}$ & $4,33^{\text {ns }}$ & $0,03^{\text {ns }}$ \\
Error & 2,181 & 0,036 & 105 & 0,022 & 0,023 & 0,001 & 11,9 & 2,78 & 0,018 \\
CV $\%$ & 7,18 & 10,4 & 5,86 & 5,96 & 16,7 & 7,15 & 4,56 & 9,62 & 2,4 \\
\hline
\end{tabular}

SV: Sources of variation, CV: Coefficient of variation; SD: Stem diameter; PH: Plant height; PROD: productivity; Ca: Calcium; Mg: Magnesium; K: Potassium; P: Phosphorus; OM: Organic matter, ${ }^{*}$ Significant $(P<0.05)$; ${ }^{* *}$ significant $(P<0.001)$; ns: not significant $(P>0.05)$ 


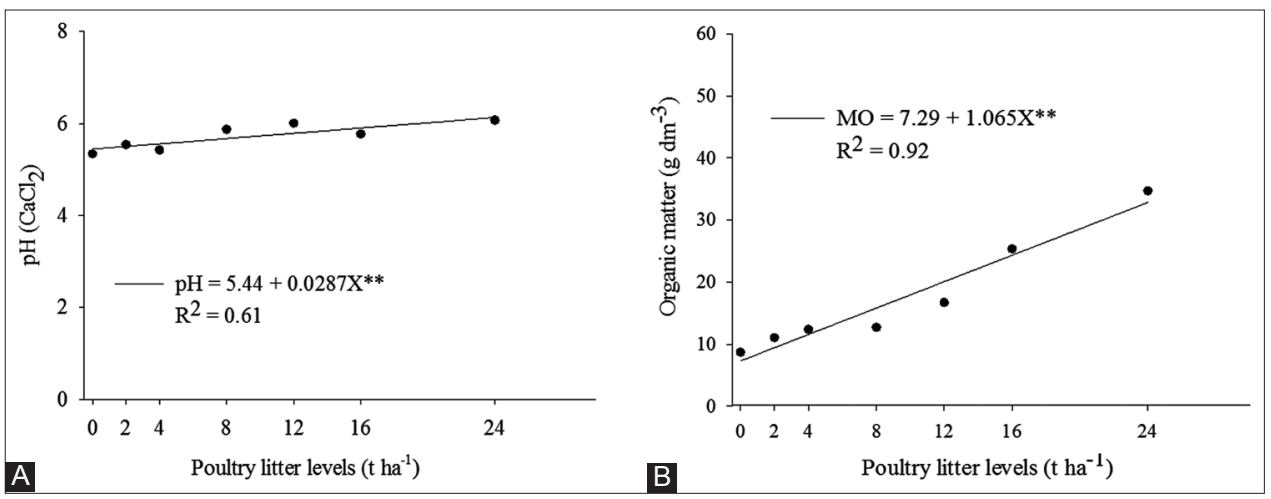

Fig 1. $\mathrm{pH}$ performed in $\mathrm{CaCl}_{2}$ solution $(\mathrm{A})$ and organic matter $(\mathrm{B})$ of the soil after application of increasing poultry litter levels. ${ }^{* *}$ significant $(\mathrm{P}<0.001)$.
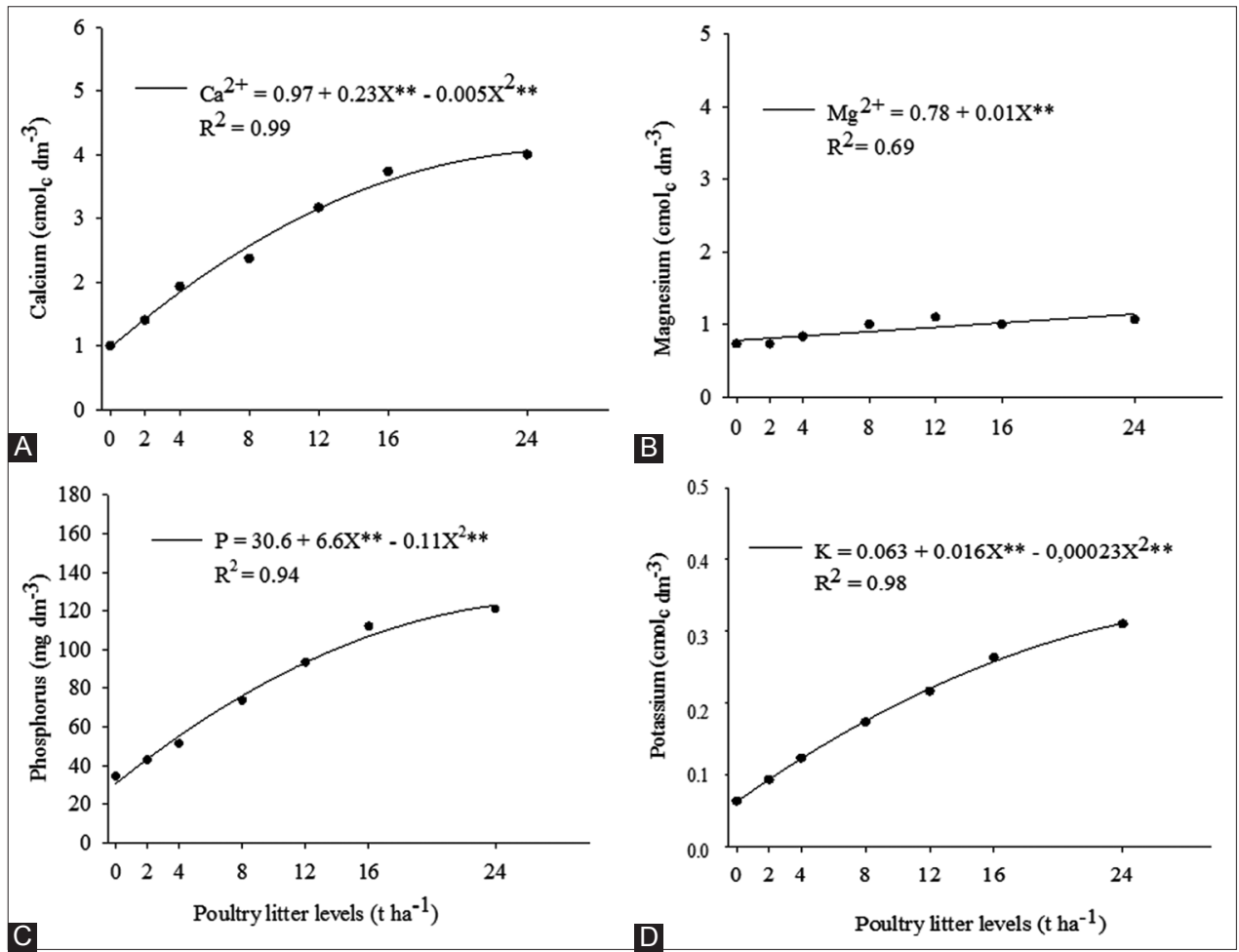

Fig 2. Calcium (A), magnesium (B), phosphorus (C) and potassium (D) contents in soil after application of increasing poultry litter levels. ${ }^{* *}$ significant $(P<0.001)$.

the doses used in a Cambisol (Carvalho et al., 2011). In a Oxisol, the use of poultry litter, during 4 consecutive years in no-tillage and conventional tillage systems, also increased $\mathrm{P}$ and $\mathrm{K}$ levels (Scherer and Nesi, 2009).

It is observed that $\mathrm{P}$ and $\mathrm{K}$ presented the highest concentration among the nutrients added by the poultry litter (Table 2). For P this can be explained because great part of this element is added in the diet and is not hydrolyzed by the birds' digestive system, being released through feces (Gianello and Ernani, 2011).

The sulfur concentration was not analyzed after poultry litter application and corn development. However, the presence of this element was verified in the poultry litter analysis (Table 2).

\section{Plants growth and corn yield}

There was a quadratic response for stem diameter (SD) in relation to the increasing poultry litter levels (Fig. 3A). The dose of $16 \mathrm{tha}^{-1}$ was responsible for the largest SD $(23 \mathrm{~mm})$. However, the dose of $24 \mathrm{t} \mathrm{ha}^{-1}$ reduced the SD to $20.9 \mathrm{~mm}$. Normally, this parameter presents a positive correlation with yield because it is a reserve organ of the plant, and its behavior directly influences in grain yield (Cruz et al., 2008).

Corn yield increased linearly as poultry litter levels (Fig. 3B). Without poultry litter fertilization, the yield was 
Table 4: Correlation analysis between the components evaluated in the plant and soil chemical attributes

\begin{tabular}{lcccccccc}
\hline & $\mathrm{Ca}$ & $\mathrm{Mg}$ & $\mathbf{K}$ & $\mathbf{P}$ & $\mathrm{OM}$ & $\mathrm{pH}$ & DC & AP \\
\hline DC & $0.64^{*}$ & $0.57^{*}$ & $0.56^{*}$ & $0.6^{*}$ & $0.49^{*}$ & $0.52^{*}$ & & \\
AP & $0.47^{*}$ & $0.2 \mathrm{~ns}$ & $0.46^{*}$ & $0.46^{*}$ & $0.39^{*}$ & $0.43^{*}$ & $0.61^{*}$ \\
PROD & $0.75^{* *}$ & $0.26 \mathrm{~ns}$ & $0.79^{* *}$ & $0.74^{* *}$ & $0.71^{* *}$ & $0.47^{*}$ & $0.47^{*}$ & $0.6^{*}$ \\
\hline
\end{tabular}

DC: Stem diameter; AP: Plant height; PROD: productivity; Ca: Calcium; Mg: Magnesium; K: Potassium; P: hosphorus; OM: Organic matter. ${ }^{\star \star} \leq 1 \%$, ${ }^{\star} \leq 5 \%$; Ns: not significant
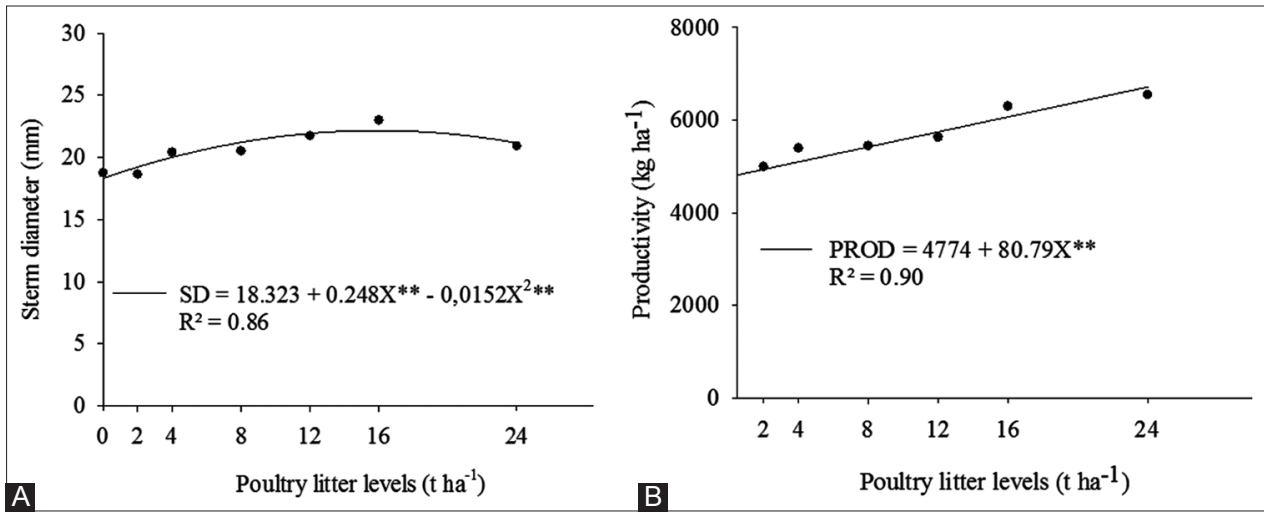

Fig 3. Stem diameter $(A)$ and corn yield $(B)$ after application of increasing poultry litter levels. ${ }^{* *}$ significant $(P<0.001)$.

4,430 $\mathrm{kg} \mathrm{ha}^{-1}$; and with the application of $24 \mathrm{tha}^{-1}$, the yield increased to $6,551 \mathrm{~kg} \mathrm{ha}^{-1}$. It was observed a $50 \%$ increase in corn yield.

These results corroborate to other studies in which increasing doses of poultry litter provided significant increase in corn yield (Bayer et al., 1999; Konzen, 2003; Novakowiski et al., 2013). Likewise, there was an increasing linear behavior of corn yield in relation to the increase of poultry litter levels in a Ultisol (Gomes et al., 2005).

The increase in yield was a result of the increase in organic matter content, $\mathrm{pH}$ and soil nutrients with the addition of poultry litter. It was evidenced by the levels in the soil after corn harvest, which were higher than the levels verified before the experiment (Figs. 2 and 3).

\section{Correlation between the variables evaluated in the plant and soil chemical attributes}

The soil chemical attributes ( $\mathrm{Ca}, \mathrm{K}, \mathrm{P}, \mathrm{OM}$ and $\mathrm{pH}$ ) correlate positively with plant height, stem diameter and yield (Table 4). Mg did not show significant correlation with plant height and yield. However there was a positive correlation with stem diameter $\left(0.57^{*}\right)$ The increase of these nutrients in the soil occurred due to the addition of poultry litter and favored the development of corn plants and, consequently, the yield increase (Fig. 1C).

The application of poultry litter as an organic fertilizer is an option that seeks the use of nutrients by crops and the environmental preservation. Therefore, it performs a socioeconomic importance, especially in the family agriculture segment as it generates profit increase and decreases environmental impacts (Santos et al., 2010). The application of animal organic residues can bring similar or even better results than mineral fertilizers, especially in sandy soils, because besides increasing the availability of nutrients, it increases organic matter contents that improve soil structure. In addition, it promotes the reduction of production costs because, in many cases, these residues are by-products in the property or in the vicinity of livestock farms.

\section{CONCLUSION}

The increasing doses of poultry litter applied in a sandy soil promote increase in corn yield. The maximum yield was obtained with the highest dose of poultry litter $\left(24 \mathrm{t} \mathrm{ha}^{-1}\right)$. The soil levels of calcium, magnesium, phosphorus, potassium, $\mathrm{pH}$, and organic matter increase as a result of the addition of increasing doses of poultry litter. The chemical attributes of the soil $(\mathrm{Ca}, \mathrm{K}, \mathrm{P}, \mathrm{OM}$ and $\mathrm{pH})$ correlate positively with stem diameter and corn yield. The poultry litter is an organic fertilizer with potential for use on sandy soil.

\section{Declarations of conflict of interest}

The authors report no declarations of conflict of interest.

\section{Authors' contributions}

Juliana da Silva Barros wrote the paper, performed the experiments, analyzed the data and coordinated the data collection. João Carlos Medeiros, Jaqueline Dalla Rosa, Julian Junio de Jesus Lacerda and Maria Sueli Heberle Mafra supported Juliana da Silva Barros in analyzed and 
data collection, writing and proofreading the paper. Daiane Conceição de Sousa supported Juliana da Silva Barros in performed the experiments, data collection and laboratory analysis.

\section{REFERENCES}

Andrade, A. S. Jr, E. A. Bastos, A. H. Barros, L. G. Jr. Figueiredo, C. Oliveira, A. A. Gomes and L. O. Peixoto. 2004. Atlas Climatológico do Estado do Piauí. Embrapa Meio-Norte, Teresina. p. 151.

Andreola, F., L. M. Costa, E. S. Mendonça and N. Olszevski. 2000. Propriedades químicas de uma Terra Roxa Estruturada influenciadas pela cobertura vegetal de inverno e pela adubação orgânica e mineral. Rev. Bras. Ciência Solo. 24: 609-620.

Bayer, C., C. A. N. Ceretta and G. Schneider. 1999. Viabilidade da utilização de cama de aviário como fertilizante na cultura do milho. Rev. Ciência Rural. 2: 10-14.

Blum, L. E. B., C. V. T. Amarante, G. Güttler, A. F. Macedo, D. A. Kothe, G. P. Simmler and L. Guimarães. 2003. Produção de moranga e pepino em solo com incorporação de cama aviária e casca de pinus. Hort. Bras. 21: 627-631.

Brady, N. C. 2013. Elementos da natureza e propriedades dos solos. In: Brady, N. C., R. R. Weil (Eds.), Matéria Orgânica do Solo, Ecossistemas Tropicaise Subtropicais. Metrópole, Porto Alegre, p. 412.

Carvalho, E. R., P. M. Rezende, M. J. B. Andrade, A. Martins, A. Passos and J. A. Oliveira. 2011. Fertilizante mineral e resíduo orgânico sobre características agronômicas da soja e nutrientes no solo. Rev. Ciência Agron. 42: 930-939.

Cruz, J. C. E., I. A. F. Konzen, I. E. P. Filho, I. Marriel., J. Cruz, M. Duarte. F. O. Oliveira and R. C. Alvarenga. 2008. Produção de Milho Orgânico na Agricultura Familiar. Circular Técnico, Embrapa Sete Lagoas MG, p. 81.

Embrapa Solos. 2013. Sistema Brasileiro de Classificação de Solos. SiBCs. $3^{\text {rd }}$ ed. Centro Nacional de Pesquisa de Solos, Rio de Janeiro, p. 353.

Embrapa Suínos and Aves. 2015. Sonho, Desafios e Tecnologia-35 Anos de Contribuições da Embrapa Suínos e Aves, Infoteca-E, Concórdia (SC).

Figueiredo, E. A. P. and J. P. G. Soares. 2012. Sistemas Orgânicos de Produção animal: Dimensões Técnicas e Econômicas, Empresa Brasileira de Pesquisa Agropecuária, Empresa Brasileira de Pesquisa Agropecuária, Brasil.

Fonseca, K., L. Schmid, J. C. Medeiros, F. Mielezrski and J. D. Rosa. 2016. Organic fertilization: Answer in the sugarcane development (Saccharum officinarum L.). Am. J. Exp. Agric. 12: 1-6.

Furtini, N. A. E., F. R. Vale, A. V. Resende, L. R. G. Guilherme and
G. A. A. Guedes. 2001. Fertilidade do Solo, Lavras., UFLA/ FAEPE, p. 252.

Gianello, C. and P. R. Ernani. 2011. Rendimento de matéria seca de milho e alterações na composição química do solo pela incorporação de quantidades crescentes de cama de frangos, em casa de vegetação. R. Bras. Ciência. Solo. 7: 285-290.

Gomes, J. A., C. A. Scapim, A. De Lucca, P. S. V. Filho, E. Sagrilo and F. Mora. 2005. Adubações orgânica e mineral, produtividade do milho e características físicas e químicas de um Argissolo Vermelho-Amarelo. Acta Sci. Agron. 27: 521-529.

Konzen, E. A. 2003. Fertilização de Lavoura e Pastagem com Dejetos de Suínos e Cama de Aves. Embrapa Milho e Sorgo. Ministério da Agricultura, Pecuária e Abastecimento, Circular Técnica, Sete Lagoas.

Konzen, E. A. and R. Alvarenga. 2005. Manejo e Utilização de Dejetos Animais: Aspectos Agronômicos e Ambientais. Ministério da Agricultura, Pecuária e Abastecimento. Circular Técnica, Sete Lagoas. pp. 63-65.

Malta, M. R., R. G. F. Pereira, S. J. R. Chagas and R. J. Guimarães. 2007. Produtividade de lavouras cafeeiras (Coffea arabica I.) em conversão para o sistema orgânico de produção. Coffee Sci. 2: 183-191.

Moreti, D., M. C. Alves, W. V. V. Filho and M. D. P. Carvalho. 2007. Atributos químicos de um Latossolo Vermelho sob diferentes sistemas de preparo, adubações e plantas de cobertura. R. Bras. Ciência. Solo. 31:167-175.

Novakowiski, J. H., I. E. Sandini, M. K. Falbo, A. De Moraes and J. H. Novakowiski. 2013. Adubação com cama de aviário na produção de milho orgânico em sistema de integração lavourapecuária. Semina. 34: 1663-1672.

Rauber, L. P., C. D. Piccolla, A. P. Andrade, A. Friederichs, A. L. Mafra, J. C. Corrêa and J. A. Albuquerque. 2005. Physical properties and organic carbon content of a rhodic kandiudox fertilized with pig slurry and poultry litter. R. Bras. Ciência. Solo. 36: 13231332.

Santos, J. F., C. H. De Brito, M. D. C. Cardoso and A. Santos. 2010. Avaliação da produção de batata-doce em função de níveis de adubação orgânica. Acta Sci. Agron. 32: 663-666.

Scherer, E. E. and C. N. Nesi. 2009. Características químicas de um latossolo sob diferentes sistemas de preparo e adubação orgânica. Bragantia. 68: 715-721.

Silva, C. A. 2008. Uso de Resíduos Orgânicos na Agricultura. Fundamentos da Matéria Orgânica do Solo. Porto Alegre., Metrópole, p. 597-621.

Walkley, A. and I. A. Black. 1934. An examination of the degtjareff method for determining soil organic matter, and a proposed modification of the chromic acid titration method. Soil Sci. 37: 29-38. 